\title{
The feasibility of offshore aquaculture and its potential for multi-use in the North Sea
}

\author{
Henrice M. Jansen ${ }^{1} \cdot$ Sander Van Den Burg ${ }^{2}$. \\ Bas Bolman ${ }^{2} \cdot$ Robbert G. Jak ${ }^{1} \cdot$ Pauline Kamermans $^{1}$ • \\ Marnix Poelman ${ }^{1} \cdot$ Marian Stuiver $^{3}$
}

Received: 17 October 2015/Accepted: 19 February 2016/Published online: 5 March 2016

(C) The Author(s) 2016. This article is published with open access at Springerlink.com

\begin{abstract}
Following the Blue Growth ambition of the European Commission, the interest in the potential of offshore is growing. This paper aimed to contribute to the discussion on the feasibility of offshore aquaculture development and its potential for multi-use with other maritime activities. A review of national and international projects forms the basis of the paper, where the Dutch North Sea is used as a case-study area. Analysis of technical, economic and ecological boundaries indicated that the potential of fish culture is limited, that seaweed cultivation is likely to gain potential when challenges related to processing will be overcome and that mussel culture has the highest potential in the near future. The North Sea is an area where many stakeholders claim space, which might set boundaries to the number of sites available for mussel culture. Competing claims are a potential source of conflict but may also lead to mutual benefits when smart combinations are sought, e.g. with wind parks, fisheries and nature conservation; especially, the possibility of combining mussel culture in or around wind parks is worthwhile to be further explored. A spatial distribution model adapted for the Dutch North Sea conditions demonstrated that offshore mussel production in wind farms can be profitable. Yet, the commercial interest for offshore development of mussel culture is still limited. Actions required to stimulate further development of the offshore mussel industry are presented for the government, the private sector, research institutes and civil society organizations.
\end{abstract}

Keywords Offshore $\cdot$ Aquaculture $\cdot$ Multi-use $\cdot$ Blue Growth

Guest editors: Elena Mente \& Aad Smaal/European Aquaculture Development since 1993: The benefits of aquaculture to Europe and the perspectives of European aquaculture production.

Henrice M. Jansen

Henrice.Jansen@wur.nl

1 IMARES Wageningen UR, Korringaweg 5, 4401 NT Yerseke, The Netherlands

2 LEI Wageningen UR, Alexanderveld 5, 2585 DB Den Haag, The Netherlands

3 ALTERRA Wageningen UR, Droevendaalsesteeg 3, 6708 PB Wageningen, The Netherlands 
Table 1 Overview of physical biochemical conditions in the Dutch North Sea

\begin{tabular}{|c|c|c|}
\hline & Range & Reference \\
\hline Depth & $11-40$ & $\begin{array}{l}\text { http://www.informatiehuismarien.nl/ } \\
\text { open-data }\end{array}$ \\
\hline Maximum wave height (m) & $10-12$ & http://www.waterberichtgeving.rws.nl \\
\hline Maximum current speed during spring tide $\left(\mathrm{m} \mathrm{s}^{-1}\right)$ & 1.6 & $\begin{array}{l}\text { http://www.waterberichtgeving.rws.nl; } \\
\text { pers. comm. RWS }\end{array}$ \\
\hline Temperature range & $6-18$ & Reijs et al. (2008) \\
\hline $\mathrm{SPM}\left(\mathrm{mg} \mathrm{l}^{-1}\right)$ & $0.9-2.0$ & Reith et al. (2005) \\
\hline Chla $\left(\mu \mathrm{g}^{-1}\right)$ & $\operatorname{Max} 20$ & http://www.watergegevens.rws.nl \\
\hline Primary production $\left(\mathrm{g} \mathrm{C} \mathrm{m}^{-2}\right.$ year $\left.^{-1}\right)$ & $120-140$ & Schrum et al. (2006) \\
\hline
\end{tabular}

\section{Introduction}

Despite high global growth rates, the European aquaculture production has stagnated since 2000 (FAO 2014). This stagnation relates to competing claims on available areas and resources, regulatory restrictions, no level playing field and other competitive factors (EC 2009a). Nevertheless, a steady increase in demand for fish has been observed (FAO 2012). The European Commission (EC) underlines the importance to increase production and competitiveness of a sustainable European aquaculture sector. The importance of aquaculture is stressed by the EC in policy documents such as the Blue Growth Strategy and the Strategic Guidelines for the sustainable development of EU aquaculture (EC 2012, 2013). Offshore aquaculture activities are highlighted as one of the areas where further growth is possible (OSPAR 2009; Troell et al. 2009; Rosenthal et al. 2012a, b) for several European basins.

The North Sea is one of the basins with potential for offshore development of aquaculture. The North Sea has been classified as a highly productive sea (McGlade 2002) with traditionally high landings of fish. Areas in the South of the North Sea are characterized by high nutrient load and high primary productivity in coastal regions, which gradually decrease when moving further offshore (Schrum et al. 2006; Troost et al. 2014), but also by high hydrodynamic forces (Table 1) that may restrict offshore use of aquaculture facilities. The current status of aquaculture in the North Sea illustrates that commercial exploitation of offshore areas is yet limited. Notwithstanding the foreseen advantages of offshore aquaculture (Stickney and McVey 2002), the feasibility of the transition towards offshore aquaculture is yet unknown (Buck et al. 2004). Such a transition may face challenges related to limited site availability and suitability, high hydrodynamic forces, concerns about environmental sustainability and spatial conflicts (Goldburg and Triplett 1997 in Frankic and Hershner 2003).

The North Sea is a crowded sea ${ }^{1}$ and development of offshore aquaculture intersects with other maritime activities, resulting in competing claims for marine space. This sets boundaries to the development of offshore aquaculture. Competing claims are, however, not only a potential source of conflict, but also windows of opportunities when scarcity of marine space increases and smart combinations of activities lead to mutual economic and ecological benefits (Van Hoof et al. 2014). Such synergies are usually driven by (1) cost-

${ }^{1}$ See e.g. this map indicating space use by different functions in the Dutch North Sea (https://www. noordzeeloket.nl/images/Noordzee\%20beleidskaart_975.pdf). 
effectiveness and (2) effective use of space (Poelman and Bolman 2010). The need for such multi-use developments is essential as competing claims are bound to increase over the next decade.

This paper aims to strengthen the framework for discussion on the potential for offshore aquaculture in the dynamic coastal seas as a stand-alone industry or in combination with other offshore activities. The Dutch North Sea is thereby used as a case-study area. The paper reviews and synthesizes information from national and international studies that have been performed over the past decade (i.e. MERMAID, COEXIST, BLUEPRINT, TripleP@Sea, Sea At Sight, MASPNOSE, ICES WGAQUA). Based on this information, the economic, technical and ecological feasibility was examined for different types of aquaculture (finfish, shellfish, seaweed). This analysis is important in the process to define the direction for future research, policy efforts and (commercial) development. It is demonstrated that cultivation of blue mussels has the highest potential in the near future, and subsequently the technical, economic and ecological conflicts and benefits for combination with other maritime activities were evaluated. Finally, requirements for the development of sustainable offshore mussel culture are proposed, aiming to identify actions to be undertaken by each of the stakeholder groups (government, the private sector, research institutes and civil society organizations).

\section{Feasibility of aquaculture in the Dutch North Sea}

Technical, ecological and socio-economic boundaries define which species have the best potential in offshore areas (Table 2). Reijs et al. (2008) performed a stepwise selection procedure to define which finfish species have the highest potential for offshore production in the Dutch North Sea (see Fig. 1 for selection criteria). This was done by evaluating the biological requirements and technological possibilities for cultured species of economic interest. Offshore operations are generally capital intensive and have high production costs, and moving offshore increases the demand for maritime infrastructures and distance to traditional logistic hubs which is both time-consuming and expensive. Offshore aquaculture systems thereby experience economic challenges, and species selected for offshore cultivation should therefore have a sufficient market value and high market demand/ penetration to compensate for high production costs. The study by Reijs et al. (2008) showed that for commercially interesting fish species temperature was either too high in summer (e.g. for species like cod) or too low in winter (e.g. for species like Bluefin Tuna), and the relative shallowness of the southern North Sea does not allow cages to be submerged (minimum depth $40 \mathrm{~m}$ ) to compensate for sub-optimal temperature conditions. They conclude that the economic and technological advancements are not considered well enough to overcome the biological boundaries for growth and production of fish in the Dutch North Sea. This is contradictive to Gimpel et al. (2015) who concluded that integrated multi-trophic aquaculture (IMTA) production with haddock, seaweed and bivalves has potential for offshore production in the German North Sea. The reason for exclusion of haddock by Reijs et al. (2008) was based on the low optimal temperatures for haddock (4-10 ${ }^{\circ} \mathrm{C}$; Fishbase) and the criteria that optimal temperature should be $>12{ }^{\circ} \mathrm{C}$ in order to deal with summer conditions.

Reijs et al. (2008) also identified four shellfish species as promising for culture in the Dutch North Sea: the blue mussel (Mytilus edulis), flat oyster (Ostrea edulis), Pacific oyster (Crassostrea gigas) and scallop (Pecten maximus). The nearshore mussel industry is the 
Table 2 Boundary conditions for fish, bivalve and seaweed culture

\begin{tabular}{|c|c|c|c|}
\hline & Technical (T) & Ecological (E) & Economic $(€)$ \\
\hline Fish & $\begin{array}{l}\text { - Maximum speeds cages } \\
\text { can withstand } \\
\left(100 \mathrm{~cm} \mathrm{~s}^{-1}\right) \text { (Kapetsky } \\
\text { et al. 2013) } \\
\text { - Potential for depth } \\
\text { adjustment (requirements } \\
\text { dependent on species) } \\
\text { (Reijs et al. 2008) } \\
\text { - Minimum speeds in } \\
\text { structures dependent on } \\
\text { species (Reijs et al. 2008) } \\
\text { - Fully resistant } \\
\text { (submergible) } \\
\text { construction to withstand } \\
\text { weather conditions, and } \\
\text { wave action, use and } \\
\text { crossover (Buck 2007b) }\end{array}$ & $\begin{array}{l}\text { - Sufficient water } \\
\text { currents to transport } \\
\text { new water to cultures } \\
\text { (input oxygen, } \\
\text { transport wastes). } \\
\text { Minimum } 10 \mathrm{~cm} \mathrm{~s}^{-1} \\
\text { (Kapetsky et al. 2013) } \\
\text { - Depth/wave height } \\
\text { excessive wave action } \\
\text { can cause } \\
\text { physiological } \\
\text { problems, reduced } \\
\text { growth, physical } \\
\text { damage and } \\
\text { mortalities (Kapetsky } \\
\text { et al. 2013) } \\
\text { - Little fouling } \\
\text { - Favourable offshore } \\
\text { grow-out environment } \\
\text { based on temperature } \\
\text { requirements of } \\
\text { representative fish } \\
\text { (Kapetsky et al. 2013) }\end{array}$ & $\begin{array}{l}\text { - Extra costs offshore } \\
\text { production (transport, } \\
\text { personnel) }\end{array}$ \\
\hline Bivalves/mussels & $\begin{array}{l}\text { - Fully resistant construction } \\
\text { to withstand weather } \\
\text { conditions, and wave } \\
\text { action, use and crossover } \\
\text { (Buck 2007b) } \\
\text { - Reliable and robust harvest } \\
\text { method (Cheney et al. } \\
\text { 2010) } \\
\text { - Fully balanced floatation } \\
\text { (Daley 2010; in } \\
\text { Kamermans et al. 2011) } \\
\text { - Infrastructure (logistics) } \\
\text { (Reijs et al. 2008) }\end{array}$ & $\begin{array}{l}\text { - Sufficient supply of } \\
\text { organic food material } \\
\text { - Sufficient water } \\
\text { currents to transport } \\
\text { new water to cultures } \\
\text { (input food, transport } \\
\text { wastes) } \\
\text { - Sufficient growth } \\
\text { (Langan and Horton } \\
\text { 2003) } \\
\text { - Sufficient spat fall } \\
\text { (Van Nieuwenhove } \\
\text { 2008) } \\
\text { - Avoidance of loss of } \\
\text { mussels that fall off the } \\
\text { ropes (Mille and } \\
\text { Blachier 2009; in } \\
\text { Kamermans et al. 2011) } \\
\text { - No pollution: neither } \\
\text { contaminants nor } \\
\text { parasites (Buck 2007a; } \\
\text { Van Nieuwenhove } \\
\text { 2008) } \\
\text { - No excessive predation } \\
\text { (Mille and Blachier } \\
\text { 2009; in Kamermans } \\
\text { et al. 2011) } \\
\text { - No excessive fouling of } \\
\text { other organisms } \\
\text { (Cheney et al. 2010) } \\
\text { - Depth > 20 m } \\
\text { (Langan and Horton } \\
\text { 2003) }\end{array}$ & $\begin{array}{l}\text { - Extra costs offshore } \\
\text { production } \\
\text { - Capital of } \\
\text { stakeholders/participants } \\
\text { (Reijs et al. 2008) } \\
\text { - Clear agreements and clear } \\
\text { marking to allow sailing } \\
\text { traffic (Buck 2007b; Van } \\
\text { Nieuwenhove 2008) } \\
\text { - Long-term investment } \\
\text { programs } \\
\text { - Long-term licensing and } \\
\text { policy }\end{array}$ \\
\hline
\end{tabular}


Table 2 continued

\begin{tabular}{|c|c|c|c|}
\hline & Technical (T) & Ecological (E) & Economic $(€)$ \\
\hline Seaweed & $\begin{array}{l}\text { - Seaworthiness systems } \\
\text { (Buck et al. 2004) } \\
\text { - Harvesting techniques } \\
\text { - Processing techniques to } \\
\text { obtain high-value products }\end{array}$ & $\begin{array}{l}\text { - Sufficient nutrients } \\
\text { available } \\
\text { - No excessive fouling } \\
\text { of other organisms } \\
\text { - Species robust to harsh } \\
\text { conditions } \\
\text { - Growth models } \\
\text { resulting in accurate } \\
\text { time interval for } \\
\text { harvest (Buck et al. } \\
\text { 2004) } \\
\text { - Minimum depth 5-8 m } \\
\text { (Buck et al. 2004) } \\
\text { - Concentrations of } \\
\text { dissolved } \mathrm{O}_{2} \text { and } \mathrm{CO}_{2} \\
\text { and a good } \\
\text { transparency of the } \\
\text { water column } \\
\text { stimulate algal growth } \\
\text { (Buck et al. 2004) }\end{array}$ & $\begin{array}{l}\text { - Extra costs offshore } \\
\text { production (transport, } \\
\text { personnel) } \\
\text { - Availability of cheap } \\
\text { seedlings (hatchery) } \\
\text { - Well-organized seeding and } \\
\text { pre-cultivation strategy } \\
\text { adapted to early transfer of } \\
\text { young cultured } \\
\text { sporophytes into the sea } \\
\text { (Buck and Buchholz 2005) }\end{array}$ \\
\hline
\end{tabular}

most important and well-established industry in the Netherlands (Smaal 2002), with an estimated total of 50 active companies and a total sales value of 48-49 million euro (Guillen and Motova 2013; EC 2014a). In this section, the mussel industry is therefore further elaborated. Total production of mussels in the Netherlands peaked in the period 1994-1999 at ca. 100 million kg annually. Since then, supply of mussel seed has decreased due to legislative restriction and lack sufficient natural spat fall, causing production levels to decrease to ca. 30 million kg annually in the years 2011-2013 (CBS 2014). There are indications that carrying capacity and environmental pressures may hinder further production growth in the traditional culture areas (Smaal et al. 2013), and there is increasing concern about the sustainability of traditional methods for mussel seed fishing from natural beds (Smaal 2002; Walter and Liebezeit 2003). Although these concerns seem an incentive to expand both seed collection and/or production of market size mussels towards offshore areas, commercial interest is currently limited. It has been proven that submerged longline systems can successfully be implemented for extreme wave height and current speed conditions with the restriction that depth should be at least $20 \mathrm{~m}$ (Langan and Horton 2003). However, current predictions show that wave height in the North Sea is extreme and can be up to $12 \mathrm{~m}$ (MIE 2015), and it is unknown whether these systems withstand such forces. An economic feasibility of offshore mussel production within areas used by wind farms in the German Bight concluded that suspended mussel culture with longlines in offshore areas can be profitable (Buck et al. 2010). Biological and technical cultivation seems feasible for a wider range of species such as the Pacific oyster, the flat oyster and scallops. However, the economic projections for these species are yet uncertain (Gimpel et al. 2015; Pogoda et al. 2011; Reijs et al. 2008).

The seaweed industry in the Netherlands is in its infancy. Hence, a high level of uncertainty exists for production estimates and economic projections (van den Burg et al. 2013). The native species Ulva sp., Laminaria sp. and Palmaria sp. have highest potential 
Fig. 1 Procedure applied by Reijs et al. (2008) for selection of fish species with potential for cultivation in the North Sea

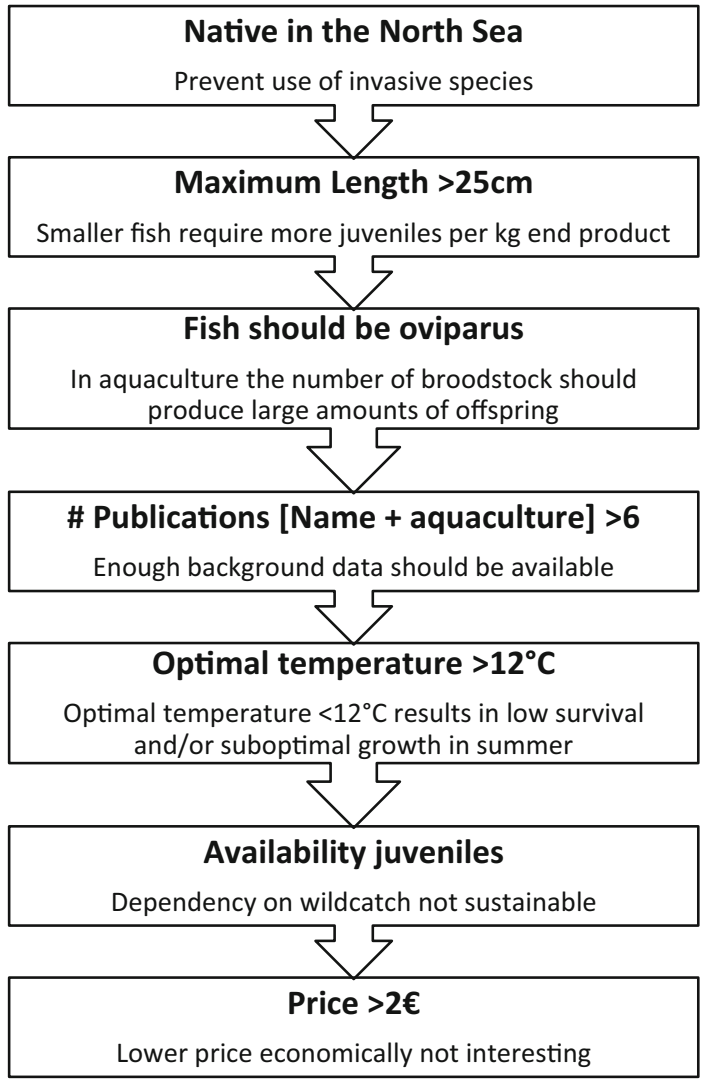

(Reith et al. 2005; van den Burg et al. 2013). Productivity of these seaweeds is high, but the growth season is restricted to summer (Ulva sp.) or winter (Laminaria sp.) season (Reith et al. 2005). Culture protocols and strategies specifically adapted for offshore cultivation conditions are needed for expansion of the sector (van den Burg et al. 2013). One aspect of adaptation to high current velocities $\left(>2 \mathrm{~m} \mathrm{~s}^{-1}\right)$ and waves $(>6 \mathrm{~m})$ includes lower seeding densities of sporophytes (Buck and Buchholz 2005). Simultaneously with the development of cultivation techniques, processing of macro-algae needs to be further developed as a preliminary economic feasibility study showed that viable seaweed culture is only possible provided that high-value products can be obtained (van den Burg et al. 2013). It is expected that when challenges related to processing of seaweeds will be overcome, seaweed cultures gain significant potential for offshore production (van den Burg et al. 2013).

In sum, cultivation of lower trophic species such as bivalves and seaweeds has highest biological and economic potential for offshore production on in the Dutch North Sea, while the potential for fish culture is limited. The most likely sector to move to offshore areas in the near future is the mussel aquaculture sector, for which the biological, technical and economic potential seems most promising. Several initiatives for pilot scale offshore mussel culture have been established over the past decade (Kamermans et al. 2011), but technical feasibility at commercial scale still needs to be proven. Additionally, there are still knowledge gaps on the ecological performance, for example on spat fall, growth, predation and biosecurity issues (HAB, pollution) (Kamermans et al. 2011). 


\section{How to fit offshore mussel culture in a crowded Sea}

The available space in the North Sea is also used by other maritime activities or set aside for nature conservation objectives. We therefore explore the ecological, technical and economic conflicts and benefits arising from multi-use of space between mussel cultures and other sectors, in order to identify whether multi-use is a viable solution for efficient use of maritime space.

\section{Site selection and multi-use combinations}

The species selection procedure used large-scale evaluation criteria, which can also be defined as macro-siting parameters: the biochemical conditions need to match the requirements of cultured species, and the hydrodynamic conditions define the technical possibilities for successful culture. Based on macro-siting parameter, thresholds Kapetsky et al. (2013) confirm that there is a large potential for mussel culture in the North Sea. This indicates that large areas are potentially available, but there are of course differences between foreseen culture areas, and micro-siting optimization approaches are required to assess exact wave and current loads onto aquaculture structures (Benassai et al. 2014) and ecological performance of the mussels. Benetti et al. (2010) emphasize that although macro-siting methods can provide important information for site assessment, a very careful in situ survey is mandatory to evaluate the suitability at micro-siting level. Investigations of natural abundance of mussels on navigation and monitoring buoys demonstrated that mussels are present in the entire Dutch North Sea (Steenbergen et al. 2005; Kamermans et al. 2016). Conditions for growth are good as the mussels on the buoys reach an average size of $65 \mathrm{~mm}$ in 15 months (Kamermans et al. 2016). Studies evaluating micro-siting of mussel farms in the North Sea have not yet been performed.

Apart from specific environmental requirements, site selection should also address legal and logistic issues (Naylor et al. 2000; Stickney and McVey 2002; Stuiver et al. 2012; Benetti et al. 2010). The Dutch North Sea is used by fisheries, tourism, shipping, oil and gas extraction, cables and pipelines, gravel extraction and wind parks, but also contains areas set aside for Marine Protected Areas (MPAs) such as Natura 2000 areas $^{1}$ (Jongbloed et al. 2014, see also Table 3). These activities and MPAs may limit the selection of sites available for aquaculture or set specific requirements for aquaculture development. Combinations between mussel culture and other maritime activities may lead to (mutual) benefits, but conflicts may also arise when the same ocean space is shared. The COEXIST project (Poelman and Bolman 2010; Stelzenmüller et al. 2013) evaluated combinations between aquaculture and other sectors for the North Sea (see adapted results in Table 3). It was concluded that some combinations are not feasible because economic and/or safety risks are too high. Most potential was identified for combinations of aquaculture with wind parks, certain types of fishery and nature conservation; especially, the potential for the combination with wind parks is considered as worthy to be explored (Buck et al. 2004; Benassai et al. 2014; Lagerveld et al. 2014; Gimpel et al. 2015). The benefits of combining these activities are expected from co-use of space, improvement of the company's corporate social responsibility (Lagerveld et al. 2014), and combined operations and management $(\mathrm{O} \& \mathrm{M})$ may lead to a reduction in costs. Hesitancy from the wind energy sector stems from the risks of damage, higher insurance costs and increase in ecological risks. 
Table 3 Potential Risks and Synergies between (bivalve) aquaculture and other marine offshore activities in the Dutch North Sea, in terms of technical (T), economic ( $€$ ), ecological (E) and Governance (G) aspects (Adapted from Poelman and Bolman 2010, with selection for offshore development only)

\begin{tabular}{lll}
\hline Offshore sector & \multicolumn{2}{l}{ Bivalve aquaculture } \\
\cline { 2 - 3 } & Risk & Synergy \\
\hline
\end{tabular}

Wind

Currently 2 operational farms $(108+120 \mathrm{MW})$, another 2 are close to operation $(129+600 \mathrm{MW})$

Aim: 4450 MW wind energy by 2020 , which implies $1000 \mathrm{~km}^{2}$ marine space. (Lagerveld et al. 2014)

\section{Fishery}

Most abundant in Dutch EEZ are bottom, pelagic, otter trawling (Oostenbrugge 2010)

There are differences in distribution patterns and total effort (Beare et al. 2010)

\section{Nature}

All of the North sea should be managed according to the ecosystem approach

Natura 2000 areas are the most relevant MPAs

\section{Oil and gas}

In the Dutch EEZ, approximately ten oil and 120 gas locations are in use.

\section{Shipping and transport}

Shipping in Dutch waters consists of cargo ships, tankers and container ships visiting Rotterdam harbour (approximately 33,000 ships/year)

\section{Cables and Pipelines}

Many cables (telecommunication) and pipelines (oil, hydrocarbons and condensate) are present in the Dutch EEZ
(T) Damage of structures wind farm by mechanical loads, or vessel anchoring

(€) Complicated Insurance programs

$(€)$ Extended financial input to secure structures

(T) Complex construction demands

(G) Lack of consensus

(G) Competing claims

(€) Damage of aquaculture structure by fisheries

(E) Impact on carrying capacity and cascading effects throughout food web

(E) Benthic impacts

(E) Disturbance of seabirds and mammals by boat activity

(E) Negative (environmental) image aquaculture

(E) Contamination of cultured species

(€) Loss of harvest in case of spillage events

(T) Safety concerns

(T) Fixed equipment introduce safety risks

Shipping routes are fixed

(T) Damage due to farm or boat anchoring
(€) Combined maintenance costs

(€) Combined logistics

(€) Better development possibilities

(€) Use of space

(€) Use of existing infrastructure (boats, personnel)

$(E+€)$ Ecosystem services (can also provide profit/value if acknowledged)

(E) Biodiversity

(E) Eutrophication control

(€) Use of existing infrastructure (vessels)

(€) Access to high capital investments

(€) Left platforms can form a logistic hub for aquaculture development

(€) Use of space in case smart/flexible routes are possible

(€) Use of space

$(€)$ Use of existing infrastructure (vessels) 


\section{Ecological impact assessment of multi-use and environmental services}

The open nature of offshore farming and the high dynamic conditions in the North Sea (da Costa and Nalesso 2006) indicate that negative impacts on carrying capacity or accumulation of organic material below farms are not likely to occur rapidly. However, it is suggested that viability of commercial offshore aquaculture can only be achieved with very large installations (Lovatelli et al. 2013). For planning and up-scaling of mussel farming, carrying capacity assessments should therefore provide insight into the maximum level that can be sustained in a given sea area. The physical presence of suspended mussel culture structures does not seem to induce adverse effects on the numbers of seabirds and common seal (Roycroft et al. 2006), and although theoretically the presence of operation and maintenance vessels may cause disturbance of birds and sea mammals, this is assumed to have minor impact (Kamermans et al. 2014; Cheney et al. 2010). Traditionally, activities have been evaluated for their ecological impacts on a case-by-case basis, i.e. per project or activity in order to obtain environmental licences. Due to the fact that activities at sea increase in diversity and intensity, more attention is paid to the cumulating effects of their interacting pressures (Tamis et al. 2016) which is also required for multi-use sites.

Besides these potential impacts, mussel aquaculture also provides ecosystem services (Shumway 2011), thereby combining nature conservation and aquaculture objectives. This was also identified as one of the prospective multi-use opportunities within the COEXIST project (Poelman and Bolman 2010). Ecosystem services refer to additional functions provided by aquaculture and represent benefits the society derives from the aquaculture ecosystem, either directly or indirectly. Examples of ecosystem services are extensive, including waste assimilation, climate and water regulation, biodiversity, but also tourism and cultural services (Costanza and Folke 1997; Farber et al. 2002). One of the most acknowledged services from bivalve culture is the top-down control of eutrophication (Ferreira and Bricker 2015). The rivers Rhine and Meuse contribute to a large extend to the nutrient concentrations in the Dutch coastal zone, while offshore nutrient concentrations are less influenced by riverine inputs (Troost et al. 2014). Mussel culture thus has good potential for bioremediation purposes in coastal areas, whereas its function seems limited in far-away offshore areas in the North Sea due to the absence of anthropogenic nutrients in these areas. Mussel longlines also provide habitat for other invertebrates by providing refuges from predation, positively affecting biodiversity and environmental productivity (McKindsey et al. 2011). Other offshore activities may also enhance ecosystem services. In wind parks for example, the emergence of benthic communities on turbine foundations might benefit biodiversity (Burkhard et al. 2011). One should be aware that constructions in general may provide an additional substrate, creating habitats for species, potentially including exotic species. It has been shown that suspended bivalve culture sites can be hotspots for invasive species, including tunicate ascidians, macro-algae and molluscs (McKindsey et al. 2011).

\section{Technical risks of multi-use}

Expected lifetime of offshore structures is to a great extend determined by the risk of failures, which can be caused either by damage mechanisms such as corrosion and biofouling or by risk of mechanical loads. The question is whether combing mussel culture with other functions influences such risks and thereby affects lifetime expectation of one of the functions. Offshore aquaculture facilities are constructed to withstand the forces of the 
oceans; however, a small risk exists that structures may become loose and become a threat to other users of maritime space. The combination between mussel farming and offshore wind parks has received significant attention (Lagerveld et al. 2014; Röckmann et al. 2015). It can be assumed, for example, that a drifting longline construction may strike and damage foundations of wind turbines, gas platforms and other fixed structures and/or may create extra drag force when getting stuck around installations such as turbines. Based on risk analysis (Lagerveld et al. 2014), it was estimated that no significant structural impact damage on wind turbines could be expected, and for monopiles and gravity-based turbine foundations, no extra risk is expected when bivalve structures get stuck around the foundations, while for jacket foundations the increased drag force can theoretically result in the collapse of a wind turbine. The latter scenario is merely theoretical and only holds under the assumption of severe storms with extremely high waves and an intact aquaculture structure that is physically directly connected to the turbine foundation with $100 \%$ coverage. Despite the small risk involved with this, physical design of the combined offshore structures foreseen in the North Sea should consider such issues in order to avoid damage from one activity to the other. For example, use of suitable anchors to hold mussel cultures in place. In the case that a broken longline may not damage a turbine, it can still prevent access to the turbines and thus make maintenance impossible. This can subsequently negatively impact performance and potentially cause structural damage to the OWF. Finally, vessel anchoring from mussel operations may create another conflict as power cables and gear can entangle or may damage cables (Mee 2006). On the positive side, as public and boat access is restricted in wind park areas, mussel cultivation sites are protected from external influences such as accidental boat collision (Buck et al. 2008).

\section{Financial conflicts and benefits of multi-use}

Studies determining economic feasibility of offshore aquaculture in general (Kapetsky et al. 2013) and for mussel culture (Buck 2007b) and multi-use platform (MUP) systems specifically are scarce. Reliable information on site-specific costs and benefits is difficult to access (Guillen and Motova 2013). Jin et al. (2005) argue that the management of risk and uncertainty is one of the most important issues on open-ocean aquaculture development. Financial risks stem from high operating costs in combination with uncertain yields and revenues (Shainee et al. 2013; Sulaiman et al. 2013). Although the synergy between offshore aquaculture and wind parks is subject to investigation (van den Burg et al. 2013; Röckmann et al. 2015), there is considerable uncertainty about financial benefits. Benefits are expected from combined operations and maintenance (Michler-Cieluch et al. 2009; Lagerveld et al. 2014; Griffin et al. 2015). Negative effects may come from increased costs for insurance in multi-use setting where multiple production functions (e.g. wind energy production) could be disrupted by failure of the mussel cultivation systems.

To investigate the economic benefits for the co-production of mussels and offshore wind energy, a case-study for the North Sea was carried out here. A spatial distribution model was developed to examine whether vacant space in offshore wind parks can be used for mussels production. This approach included (1) a simple linear optimization model to analyse how vacant space can be used in the best manner, and (2) sensitivity analyses to examine the effects of changes in input parameters (see Table 4). A hypothetical offshore mussel farm was designed, using longlines between monopiles. The production system uses separate longlines for mussel spat collection, for first growing and for maturation (in a ration 1:4:16). Mussels are harvested and re-attached to the longlines twice before they are harvested for consumption. Total growth period is set at 18 months, based on Steenbergen 
Table 4 Optimization model assessing the economic benefits of combining mussel and wind farming

\begin{tabular}{lll}
\hline Variable & Start value & Breakeven point (all other variables equal) \\
\hline Mussel price $(€$ tonnes & -1 \\
Mussel production $\left(\right.$ tonnes $\left.\mathrm{ha}^{-1}\right)$ & 0.92 & 0.66 \\
Fixed cost $\left(€ \mathrm{ha}^{-1}\right)$ & 41.5 & 29.5 \\
Repair cost $\left(€ \mathrm{ha}^{-1}\right)$ & 25,671 & 36,771 \\
Transport cost $\left(€ \mathrm{ha}^{-1}\right)$ & 533 & \\
Labour cost $\left(€ \mathrm{ha}^{-1}\right)$ & 4306 & 15,306 \\
Other variable cost $\left(€ \mathrm{ha}^{-1}\right)$ & 1489 & \\
Price elasticity & 267 & \\
\hline
\end{tabular}

Model description, assumptions and input variables. Input variables are based on Buck et al. (2010), Van Stralen (2013) and pers comm Machinefabriek Bakker (expressed in $€$ or tonnes ha ${ }^{-1}$ )

Assumptions: (1) Construction of the wind park is a given. (2) Both wind park and aquaculture belong to the same owner; transaction costs are therefore excluded. (3) Constructions are not co-used. Although this is described to be beneficial (Buck 2004), stakeholder consultation indicated that there is no support for this (Röckmann et al. 2015). (4) Synergy is expected in the labour, harvesting and transport. (5) Mussel culture based on longline cultivation techniques, including five systems per hectare. (6) Lifespan of a longline system is set to 4 years. (7) Production is based on natural spat fall and growth estimates (Steenbergen et al. 2005, Kamermans et al. in prep). (8) Mussel production outside study area stays constant

et al. (2005) and Kamermans et al. (2016). The length of the longlines is set at $2.4 \mathrm{~km}$ per ha, with an expected yield of $10.000 \mathrm{~kg}$ mussels per km (Walter and Liebezeit 2003; Buck et al. 2010). The costs for offshore mussel production are estimated using Buck et al. (2010). In the model, it is assumed that synergies exist between aquaculture and wind farms, from shared transport and operations and maintenance (O\&M), and is set at $5 \%$ (Lagerveld et al. 2014). This means that the wind park operator costs for O\&M are reduced by $5 \%$ if mussel aquaculture takes place in the park. No synergy is expected from infrastructure and installations as this would increase risks.

Based on these input parameters, the model shows that offshore mussel production in wind farms can be profitable. With 1000 ha of mussel production and a total production of 41.5 thousand tonnes, overall profit is $€ 9$ million with revenues of $€ 39$ million and total cost set at $€ 30$ million. Given the declining production levels in recent years, it is assumed that there is a market demand for this quantity of extra production (BluePort 2012; Guillen and Motova 2013). The input parameters are subject to uncertainty, and sensitivity analysis was therefore performed on the economic consequences of changes in (1) lower base price for mussels, (2) lower mussel yield, (3) higher cost for mussel production and (4) higher transportation costs for mussels. Result of the analysis shows that growing mussels are no longer profitable if the price of mussels drops below $0.66 € \mathrm{~kg}^{-1}$, equalling a price drop of $28 \%$. The break-even point is also reached when production drops from $41.5 \mathrm{tha}^{-1}$ to $29.5 \mathrm{t} \mathrm{ha}^{-1}(-29 \%)$, if fixed costs increase from 26,674 to $36,771 € \mathrm{ha}^{-1}$ (+43\%), or if transport costs increase from 4306 to $15,306 € \mathrm{ha}^{-1}$ (+255\%).

\section{Requirements for further development of offshore mussel culture}

Based on macro-evaluation criteria, it appears that offshore mussel culture is feasible, both as a single-use activity ('Feasibility of aquaculture in the Dutch North Sea' section) and as a multi-use setting ('How to fit offshore mussel culture in a crowded Sea' section). There 
appears to be an incentive to search for new cultivation areas as environmental pressure hinders further production growth in the traditional culture areas (Smaal et al. 2013), while at the same time market predictions indicate that higher volumes can be realized (BluePort 2012). Nonetheless, this has not yet ignited commercial interest, and to date, industry participation in offshore areas is limited. Successful development of mussel aquaculture in offshore areas is, however, not solely the responsibility of the industry. This is particularly the case for multi-use developments where success also relies on regulatory frameworks, which can stimulate or counteract the adoption of multi-use concepts (Lagerveld et al. 2014). Hence, governments, research institutes and civil society organizations should also take responsibility in order to find sustainable, resource- and space-efficient solutions for single and combined ocean use. The last section of this paper therefore outlines needs and actions required from these four stakeholder groups to realize a competitive offshore mussel industry in the Dutch North Sea.

\section{Marine spatial planning}

The spatial planning of coastal and offshore marine areas is an emerging responsibility of policy-makers from national governments, and it is their responsibility to allocate sites available for offshore mussel culture and encourage innovations being developed. Marine spatial planning (MSP) is a key tool to balance sector interests and achieve sustainable use of marine resources in line with the EU Sustainable Development Strategy (EC 2008; Maes et al. 2012). The aim of MSP is to make the trade-offs in marine resource use and sector values explicit (White et al. 2012). Such approaches have not yet been applied to planning of mussel culture and multi-use development in the North Sea. The value of making tradeoffs explicit is demonstrated by Ferreira et al. (2014) who illustrate that development of mussel culture in offshore areas potentially reduced yields for inshore shellfish cultures in southern Portugal. Ferreira et al. (2014) thereby illustrated that dynamic models make a valuable contribution in assessing the feasibility of offshore culture and the general principles that underpin MSP, licensing and regulation of this sector.

When the national governments create an enabling environment for offshore mussel cultures, it has to proclaim and invest in the governance of these new activities in combination with other (multi-use) activities at sea. This can be done with the help of the ten MSP rules (EC 2008; Maes et al. 2012):

1. Operate within four dimensions, addressing activities (1) on the seabed, (2) in the water column, (3) on the surface and (4) the time dimension;

2. Include detailed objectives for the strategic management plan for the area;

3. Transparency is needed for all documents and procedures;

4. Involve all stakeholders at the earliest possible stage in the planning process;

5. Coordination with member states, simplify decision processes and speed up licensing and permit procedures;

6. MSP should be legally binding, and appropriate administrative frameworks should be in place;

7. Cooperation across borders is necessary to ensure coherence of plans across ecosystems;

8. Incorporate monitoring and evaluation in the planning process;

9. Achieve coherence between terrestrial and maritime spatial planning;

10. Planning needs to evolve with knowledge (adaptive management) and quality assurance on data and knowledge. 


\section{Legislation}

Most activities at the Dutch EEZ are subject to licensing procedures, in order to protect nature and environment, and to guarantee safety at sea (EEC 1992; EC 2009b; MANFQ 1998a, b; MTW 2009). Aquaculture activities are not subject to a formal Environmental Impact Assessment based on Directive 2014/52/EU (EC 2014b), but culture sites, whether experimental or commercial, are subject to licences based on the Fisheries Act (MAF 1963). In 2011, temporary licences for experimental mussel culture in the North Sea were provided by the Dutch government (MEAAI 2011). The size of such an experimental site should not exceed three hectares, and licences were provided for a period of 3 years with possibilities for a 5-year extension. Even though permits were issued, culture trials were not started. Industrial and investors participation in new activities are generally based on a long-term strategy for the development of sites and technologies to enable a return on investment. This requires the support of long-term investment potential, and long-term licensing and policies.

The policy context for combinations of maritime functions is developing. Despite the interest in combining functions in policy documents (MIE 2014), laws and regulations do not foresee in such combinations. Until recently, the concessions granted to offshore wind park operators made co-use illegal. Since 2015-following a parliamentary notion-it is now under discussion whether wind park operators should be obliged to study the possibilities for co-use (MEA 2015).

\section{Investment and innovation}

Access to capital markets is a driver towards more intensive forms of processing and production as well as the acquisition of other enterprises (VPS 2008). History in successful developed salmon aquaculture demonstrates that growth purely through organic expansion is unlikely to deliver a globally ranked enterprise (Asche et al. 2013). It is also believed that real breakthrough of sector development should come from radical innovation (Utterback 1974; Gatignon and Xuereb 1997; Tidd et al. 2003). At present, the majority of innovations applied by the Dutch shellfish industry are incremental, indicating gradual improvements of existing products or processes (e.g. fishing and sorting technologies) and there is no significant escape from the status-quo. Innovations that had a more radical nature were the implementation of seed mussel collectors (SMC; Kamermans et al. 2014) and modified atmosphere packaging (Brody 1989). Offshore mussel culture is facing the choice to develop on the basis of incremental innovation or to achieve a higher level by radical innovations. Such innovations need adequate management of knowledge resources, institutional involvement, technological innovations and foremost large-scale investment.

Currently, the mussel sector has low capital costs (Guillen and Motova 2013). A move to offshore sites requires investment, not only in vessels but also in longlines, mooring and buoys capable of withstanding the offshore environment. In many cases, external capital is needed to cover these expenses. The introduction of SMCs, for example, took place when capital for innovation was available (MANFQ 2004). The entrance of banks and investment funds into the mussel sector can also speed up innovation and cost reduction. To attract those investors, it is crucial to show a level of development and success yet not achieved. Investment is currently stymied by regulatory and operational uncertainties, including permitting, structural engineering, remote management tools and monitoring systems (Klinger and Naylor 2012). 


\section{Pilots sites to validate feasibility}

Pilot projects are important in the sense that they can prove a degree of reliability for technical and economic feasibility and they will be essential in shaping the future of offshore production sites (Christie et al. 2014). An important criterion for the development of a profitable offshore sector is reduction in costs per kilograms produced mussels through large production volumes and proper technology (Knapp 2013). The construction of largescale offshore culture systems still requires considerable technologically driven research (Langan and Couturier 2010) which is best initiated by a partnership between the sector and the scientific community. Public authorities play a key role here to support technology development (Mazzucato 2013). The current request for technological validation of offshore mussel culture systems may limit the degree of reliability required to be adopted in multi-use concepts and raises the question whether the offshore mussel culture should develop as a single-use or multi-use combination. It is arguable that for the short-term (pilot stage) aquaculture develops independently to reduce risks and conflicts with other users and once the technical feasibility is confirmed its potential in multi-use settings is exploited for long-term developments. Additionally, development of remote management and monitoring systems is necessary to obtain data related to culture performance without visiting the sites on a regular basis, as visiting offshore sites is both time-consuming and expensive. Remote systems can either comprise of ocean sensor networks (Nam et al. 2014), remote sensing techniques (Dean and Salim 2013) or a combination of both.

Pilot sites aim to deliver insight into the ecological performance of offshore cultures and provide information on densities, growth rates and condition indices of the mussels. Densities are largely defined by the spat fall success and predation pressure. Spat collectors should be deployed at the optimal moment to obtain successful spat fall and to prevent fouling (Fuentes and Molares 1994; Kamermans et al. in prep), but timing varies between years and locations and underlying mechanisms for settlement success are largely unknown. Compared to traditional culture areas, there are indications that quality and growth potential of mussels in offshore areas is high (Buck et al. 2005; Kamermans et al. 2016), but needs yet to be further confirmed. Furthermore, pilot sites will only be successful if managed by pioneers that are ready for innovation, willing to adopt new techniques and that are willing to continuously optimize protocols based on new insights on ecological performance and operational (un)certainties in offshore areas. Development of production and bio-economic models, as well as macro- and micro-site selection procedures, will support optimization of management protocols. It is thereby of great importance to (remotely) monitor the (a)biotic environmental conditions and shellfish performance. Food conditions in offshore areas are generally lower compared to the nearshore and inshore areas (Troost et al. 2014), which necessitates an evaluation whether modified farm designs are required to prevent food depletion within suspended farms (Rosland et al. 2011).

Finally, information from the pilot sites feed into business models, either for single-use activity or within a multi-use context. The latter should elaborate on favourable costbenefit ratios that arise from sharing operation and maintenance between the two (or more) user functions, but also specify the potential increase in costs from being in a multi-use setting, e.g. by increased insurance costs or additional investment in technical infrastructure to secure culture systems. Management and business plans start with identifying the demand side of the value chain. In other words, what are the potential market segments, 
what are the potential customers in the chain such as wholesale, retail and consumers, and what are their needs with respect to species, sizes, taste and prices (Grunert et al. 2005).

\section{Management of environmental resources}

Management of environmental resources is important in the planning and management of aquaculture sites (Dempster and Sanchez-Jerez 2008), and the Ecosystem Approach to Aquaculture (FAO 2010) should be the guiding principle. Ecosystem-based aquaculture management requires many specific components and tools for assessing the carrying capacity (Cranford et al. 2012). A bottleneck to the establishment of an operational framework is often the need to define 'unacceptable' impacts among stakeholders (Cranford et al. 2012). Suitable performance indicators, modelling approaches and indicator selection criteria must be adapted for offshore areas to facilitate policy-makers (and business) to set environmental standards and identify best practices and technologies for aquaculture development.

The economic revenues of aquaculture are often based on the market value of harvestable products, while the value of 'ecosystem services' is not fully captured in commercial markets or adequately quantified (de Groot 1987; Costanza and Folke 1997). Economic planning and decision-making for (offshore) aquaculture and/or MUP development will benefit from techniques making value of ecosystem services explicit. Such methods enable the conducting of cumulative effect assessment including both negative and beneficial impacts. Ecosystem services in general have been widely studied (Millennium Ecosystem Assessment 2005), and economic valuation has been addressed by networks such as 'The Economics of Ecosystems and Biodiversity' (Russi et al. 2013), but valorization and valuation estimates of aquaculture services are rare. One example for valuing of ecosystem services is the nutrient trading system for bivalve aquaculture, first suggested by Lindahl et al. (2005). Ferreira and Bricker (2015) indicate that this concept can have significant value, estimating the value of eutrophication reduction by shellfish culture in the EU amount to 18-26 billion $€$ per year. Due to the general lack of valuing ecosystem services, they are usually given little priority in policy decisions (de Groot 1987; Costanza and Folke 1997). Quantifying the value of aquaculture and/or MUP effects on ecosystem services is a challenge due to complex interactions. It is up to the academia to take this challenge and develop tools and frameworks for quantification and valuation of ecosystem services. To valorize these benefits and reduce the cost burden for the industry, governmental authorities are required to implement monetarization frameworks.

For industry and investor participation, long-term strategies are essential. One of the foreseen changes that may alter environmental resources is climate change, and this may alter shellfish production in the future. In the North Sea, predicted increase in temperature is $+0.8{ }^{\circ} \mathrm{C}(1990 \mathrm{~s}-2040 \mathrm{~s})$ (Philippart et al. 2011). This can cause changes in the latitudinal distribution of some species, such as species expanding outside their historical ranges into more northerly or less coastal areas (Philippart et al. 2011). Furthermore, higher temperature should favour an increase in primary production. Opportunities to culture more southern species and more biomass may arise. Rising surface water temperature will also lead to increased stratification and greater nutrient limitation. In addition, the risk of certain types of harmful algal blooms (HABs) may increase as a result of environmental conditions expected with climate change (Hallegraeff 2010). Moore et al. (2011) showed that warm air and water temperatures, low stream flow, low winds, and small tidal variability preceded $\mathrm{HAB}$ events during the past 30 years, a condition that would have significant consequences to shellfish cultivation. Extreme thermal conditions will make 
shellfish more susceptible to bacterial, viral and parasitic infections (Gubbins 2006). Also, increased carbon dioxide may cause an acidification of the oceans, which may reduce the shell growth of bivalve molluscs (Gazeau et al. 2010). And climate change can affect predator/prey relationships causing a mismatch between spawning, phytoplankton production and predator abundance and consequently high shellfish mortality (Philippart et al. 2003). The net result of climate change is hard to predict. Eco-physiological modelling (Ferreira et al. 2008) and monitoring of expected changes are advised to be able to prepare for the future.

\section{Stakeholder participation}

Participative research and policy-making are required to enhance the innovation needed for successful development of an offshore mussel industry. The participatory turn reflects the movement from top-down planning to participation in planning and design and is associated with a number of benefits, such as more democratic decision-making, increased support for the policies design and better design (Wesselink et al. 2011). The key to such an approach is that stakeholders from governments, the private sector, research institutes and civil society organizations are involved from the early stages of project development (Van Slobbe 2010; van Slobbe and Lulofs 2011; van den Hoek et al. 2012). One of the results of such an approach is the so-called covenant (co-management). The process of a covenant starts with stakeholder dialogues to agree on steps towards sustainability through innovation, with the aim to find realistic solutions to considerably reduce environmental impacts. The covenant on mussel fisheries in inshore areas in the Netherlands, for example, aims at a transition from mussel seed fisheries towards implementation of the innovative SMCs, and all involved stakeholders agreed on public-private investments in the development of SMCs (MANFQ 2008).

The advantage of such approaches is the focus on co-creation. The legitimacy or acceptance of the process increases, creating the idea or assumption that co-created actions are desirable, appropriate within a socially constructed system of norms, values, beliefs and definitions (Suchman 1995). By involving stakeholders in a process, the potential for conflicts at later stages in the project is likely to be reduced, and it is argued that the quality and durability of decisions is greater (Reed 2008). The EU Marine Spatial Planning Directive (EC 2014c) emphasizes the importance of participation in spatial planning for the North Sea. Various research projects (e.g. MASPNOSE; Douvere 2008; Pomeroy and Douvere 2008) indicated that direct negotiations between stakeholders and authorities could benefit from participatory approached in MSP and to settle mutual beneficial arrangements in covenants. The inclusion of stakeholders was generally regarded as a solution to a more coherent planning in order to make better use of beneficial opportunities in case different functions are to be combined. This indicates that in the design and planning of offshore mussel culture, whether stand-alone or in a multi-use context, it is essential to bring all stakeholders together.

Open Access This article is distributed under the terms of the Creative Commons Attribution 4.0 International License (http://creativecommons.org/licenses/by/4.0/), which permits unrestricted use, distribution, and reproduction in any medium, provided you give appropriate credit to the original author(s) and the source, provide a link to the Creative Commons license, and indicate if changes were made. 


\section{References}

Asche F, Roll KH, Sandvold HN, Sørvig A, Zhang D (2013) Salmon aquaculture: larger companies and increased production. Aquac Econ Manag 17(3):322-339

Beare D, Rijnsdorp A, Van Kooten T, Fock H, Schroeder A, Kloppmann M, Witbaard R, Meesters E, Schulze T, Blaesbjerg M, Damm U, Quirijns F (2010) Study for the Revision of the plaice box-Final Report. Report number C002/10, Wageningen IMARES

Benassai G, Mariani P, Stenberg C, Christoffersen M (2014) A sustainability index of potential co-location of offshore wind farms and open water aquaculture. Ocean Coast Manag 95:213-218

Benetti DD, Benetti GI, Rivera JA, Sardenberg B, O’Hanlon B (2010) Site selection criteria for open ocean aquaculture. Mar Technol Soc J 44:22-35

BluePort (2012) Blueport Oosterschelde Innovatieprogramma. http://oosterschelde.blueportal.nl/public/ oosterschelde/concept-innovatieprogramma_bpo.pdf (in Dutch)

Brody AL (1989) Modified atmosphere packaging of seafoods. In: Brody AL (ed) Controlled/modified atmosphere/vacuum packaging of foods. Food Nutrition Press Inc., Connecticut, pp 59-65

Buck BH (2004) Farming in a high energy environment: potentials and constraints of sustainable offshore aquaculture in the German Bight (North Sea). Ph.D. thesis, University of Bremen (Germany)

Buck BH (2007a) Farming in a high energy environment: potentials and constraints of sustainable offshore aquaculture in the German Bight (North Sea). Berichte zur Polar-und Meereforschung 543. ISSN 1618-3193. http://epic.awi.de/26716/1/BerPolarforsch2007543.pdf

Buck BH (2007b) Experimental trials on the feasibility of offshore seed production of the mussel Mytilus edulis in the German Bight: installation, technical requirements and environmental conditions. Helgol Mar Res 61(2):87-101

Buck BH, Buchholz CM (2005) Response of the offshore cultivated Laminaria saccharina to hydrodynamic forcing in the North Sea. Aquaculture 250:674-691

Buck BH, Krause G, Rosenthal H (2004) Extensive open ocean aquaculture development within wind farms in Germany: the prospect of offshore co-management and legal constraints. Ocean Coast Manag 47(3-4):95-122

Buck BH, Thieltges DW, Walter U, Nehls G, Rosenthal H (2005) Inshore-offshore comparison of parasite infestation in Mytilus edulis: implications for open ocean aquaculture. J Appl Ichthyol 21:107-113

Buck BH, Krause G, Michler-Cieluch T, Brenner M, Buchholz CM, Busch JA, Fisch R, Geisen M, Zielinski $\mathrm{O}$ (2008) Meeting the quest for spatial efficiency: progress and prospects of extensive aquaculture within offshore wind farms. Helgol Mar Res 62:269-281

Buck BH, Ebeling MW, Michler-Cieluch T (2010) Mussel cultivation as a co-use in offshore wind farms: potential and economic feasibility. Aquac Econ Manag 14(4):255-281

Burkhard B, Opitz S, Lenhart H, Ahrendt K, Garthe S, Mendel B, Windhorst W (2011) Ecosystem based modeling and indication of ecological integrity in the German North Sea-case study offshore wind parks. Ecol Ind 11(1):168-174

CBS Statline (2014) Zee- en kustvisserij; vloot, visvangst en productie aquacultuur. http://statline.cbs.nl/ StatWeb/publication/?DM=SLNL\&PA=7203VLOO\&D1=13-45\&D2=6-26\&HDR=G1 \&STB= $\mathrm{T} \& \mathrm{VW}=\mathrm{T}$ (in Dutch)

Cheney D, Langan R, Heasman K, Friedman B, Davis J (2010) Shellfish culture in the open ocean: lessons learned for offshore expansion. Mar Technol Soc J 44:55-67

Christie N, Smyth K, Barnes R, Elliott M (2014) Co-location of activities and designations: a means of solving or creating problems in marine spatial planning? Mar Policy 43:254-261

Costanza R, Folke C (1997) Valuing ecosystem services with efficiency, fairness and sustainability as goals. In: Daily G (ed) Nature's services: societal dependence on natural ecosystems. Island Press, Washington, pp 49-70

Cranford P, Kamermans P, Krause G, Mazurié J, Buck B, Dolmer P, Fraser D, Van Nieuwenhove K, O’Beirn FX, Sanchez-Mata A (2012) An ecosystem-based approach and management framework for the integrated evaluation of bivalve aquaculture impacts. Aquac Environ Interact 2:193-213

da Costa KG, Nalesso RC (2006) Effects of mussel farming on macrobenthic community structure in Southeastern Brazil. Aquaculture 258:655-663

Daley B (2010) Farm-raised mussels pass first local test. Globe Newspaper Company. In: Kamermans et al. (2011)

De Groot RS (1987) Environmental functions as a unifying concept for ecology and economics. Environmentalist 7(2):105-109

Dean A, Salim A (2013) Remote sensing for the sustainable development of offshore mariculture. In: Kapetsky et al. (2013) 
Dempster T, Sanchez-Jerez P (2008) Coastal aquaculture and marine space planning in Europe: an ecological perspective. In: Holmer M, Black K, Duarte C, Marba N, Karakassis I (eds) Aquaculture in the ecosystem. Elsevier, New York, pp 87-116

Douvere F (2008) The importance of marine spatial planning in advancing ecosystem-based sea use management. Mar Policy 32(5):762-771

EC (2008) Roadmap for maritime spatial planning: achieving common principles in the EU. European Commission, Communication from the Commission. COM/2008/791

EC (2009a) Communication from the Commission to the European Parliament and the Council, Building a sustainable future for aquaculture, A new impetus for the Strategy for the Sustainable Development of European Aquaculture-COM/2009/0162

EC (2009b) Conservation of wild birds. 2009/147/EC

EC (2012) Blue Growth. Opportunities for marine and maritime sustainable growth. COM/2012/494

EC (2013) Strategic Guidelines for the sustainable development of EU aquaculture. COM/2013/229

EC (2014a) Facts and figures on the Common Fisheries Policy - Basic statistical data -2014 Edition Luxembourg. Brussels: Publications Office of the European Union, 44 p. ISBN 978-92-79-34192-2, doi: $10.2771 / 35745$

EC (2014b) The assessment of the effects of certain public and private projects on the environment. 2011/92/EU

EC (2014c) Establishing a framework for maritime spatial planning. 2014/89/EU

EEC (1992) Conservation of natural habitats and of wild fauna and flora. 92/43/EEC

FAO (2010) Aquaculture development. 4. Ecosystem approach to aquaculture. FAO Technical Guidelines for Responsible Fisheries, vol 5(Suppl. 4), FAO, Rome

FAO (2012) The State of World Fisheries and Aquaculture. FAO Fisheries and Aquaculture Department, Rome. ISBN 978-92-5-107225-7

FAO (2014) The state of world fisheries and aquaculture-opportunities and challenges. FAO Fisheries and Aquaculture Department, Rome. ISBN 978-92-5-108275-1

Farber SC, Costanza R, Wilson MA (2002) Economic and ecological concepts for valuing ecosystem services. Ecol Econ 41:375-392

Ferreira J, Bricker S (2015) Goods and services of extensive aquaculture: shellfish culture and nutrient trading. Aquac Int. doi:10.1007/s10499-015-9949-9

Ferreira JG, Saurel C, Lencart e Silva JD, Nunes JP, Vazquez F (2014) Modelling of interactions between inshore and offshore aquaculture. Aquaculture 426-427:154-164

Ferreira JG, Hawkins AJS, Monteiro P, Moore H, Service M, Pascoe PL, Ramos L, Sequeira A (2008) Integrated assessment of ecosystem-scale carrying capacity in shellfish growing areas. Aquaculture 275:138-151

Frankic A, Hershner C (2003) Sustainable aquaculture: developing the promise of aquaculture. Aquac Int 11:517-530

Fuentes J, Molares J (1994) Settlement of the mussel Mytilus galloprovincialis on collectors suspended from rafts in the Ria deArousa (NW of Spain): annual pattern and spatial variability. Aquaculture 122:55-62

Gatignon H, Xuereb JM (1997) Strategic orientation of the firm and new product performance. J Mark Res 34:77-90

Gazeau F, Gattuso JP, Dawber C, Pronker AE, Peene F, Peene J, Heip CHR, Middelburg JJ (2010) Effect of ocean acidification on the early life stages of the blue mussel (Mytilus edulis). Biogeosci Discuss 7:2927-2947

Gimpel A, Stelzenmüller V, Grote B, Buck BH, Floeter J, Núñez-Riboni I (2015) A GIS modelling framework to evaluate marine spatial planning scenarios: co-location of offshore wind farms and aquaculture in the German EEZ. Mar Policy 55:102-115

Goldburg R, Triplett T (1997) Murky Waters: Environmental Effects of Aquaculture in the United States. Environmental Defense Fund. In: Frankic and Hershner (2003)

Griffin R, Buck BH, Krause G (2015) Private incentives for the emergence of co-production of offshore wind energy and mussel aquaculture. Aquaculture 436:80-89

Grunert KG, Fruensgaard Jeppesen L, Risom Jespersen K, Sonne AM, Hansen K, Trondsen T, Young JA (2005) Market orientation of value chains: a conceptual framework based on four case studies from the food industry. Eur J Mark 39(5/6):428-455

Gubbins M (2006) Impacts of climate change on aquaculture in marine climate change im-pacts Annual Report Card 2006. In: Buckley PJ, Dye SR, Baxter JM (eds), Online Summary Reports, MCCIP, Lowestoft

Guillen J, Motova A (eds) (2013) The economic performance of the EU aquaculture sector (STECF 13-29) Scientific, Technical and Economic Committee for Fisheries (STECF) https://stecf.jrc.ec.europa.eu/ documents/43805/622206/2013-12_STECF+13-29+-+Aquaculture+economics_JRC86671.pdf 
Hallegraeff G (2010) Ocean climate change, phytoplankton community responses, and harm-ful algal blooms: a formidable predictive challenge. J Phycol 46:220-235

Jin D, Kite-Powell H, Hoagland P (2005) Risk assessment in open-ocean aquaculture: A firmlevel investment-production model. Aquac Econ Manage 9(3):369-387

Jongbloed RH, van der Wal JT, Lindeboom HJ (2014) Identifying space for offshore wind energy in the North Sea. Consequences of scenario calculations for interactions with other marine uses. Energ Policy 68(C):320-333

Kamermans P, Schellenkes T, Beukers R (2011) Verkenning van mogelijkheden voor mosselteelt op Noordzee. IMARES Rapport C021/11. http://edepot.wur.n1/166223 (in Dutch)

Kamermans P, Smit C, Wijsman J, Smaal A (2014) Meerjarige effect- en productiemetingen aan MZI's in de Westelijke Waddenzee, Oosterschelde en Voordelta. Deel 1: Inschatting ecologische effecten van opschaling. IMARES Rapport. http://edepot.wur.nl/312852 (in Dutch)

Kamermans P, Soma K, van der Burg S (2016) Haalbaarheid mosselteelt binnen offshore windparken in de Nederlandse kustzone. IMARES Rapport

Kamermans P, Broekhoven W van, Uppabullung A, Brummelhuis E, Troost K, Wetsteyn B, Herman P, Smaal AC (in prep) Settlement, retention and growth of Mytilus edulis spat on collectors in Dutch coastal waters

Kapetsky JM, Aguilar-Manjarrez J, Jenness J (2013) A global assessment of potential for offshore mariculture development from a spatial perspective. FAO Fisheries and Aquaculture Technical Paper No 549. FAO, Rome

Klinger D, Naylor R (2012) Searching for solutions in aquaculture: charting a sustainable course. Ann Rev Environ Res 37:247-276

Knapp G (2013) The development of offshore aquaculture: an economic perspective. In: Lovatelli et al. (2010)

Lagerveld S, Röckmann C, Scholl M (Eds) (2014) Combining offshore wind energy and large-scale mussel farming: background and technical, ecological and economic considerations. IMARES report number C056/14 http://www.maritimecampus.nl/sites/default/files/C056\%2014\%20Report-Blauwdruk-_SLMS-lcs.pdf

Langan R, Couturier M (2010) Chapter 24: Offshore and recirculation technologies. In: Le Francois et al. (2010) Finfish aquaculture diversification. Canada 10.1079/9781845934941.0000 https://en.uit.no/ Content/273701/CABI\%20Finfish\%20Aquaculture\%20Book.pdf

Langan R, Horton F (2003) Design, operation and economics of submerged longline mussel culture min the open ocean. Bull Aquac Assoc Can 103:11-20

Lindahl O, Hart R, Harnroth B, Kolberg S, Loo L, Olrog L, Rehnstam-Holm A, Svensson J, Svensson S, Syversen U (2005) Improving marine water quality by mussel farming: a profitable solution for Swedish Society. Ambio 34(2):131-138

Lovatelli, A, Aguilar-Manjarrez J, Soto D (eds) (2013) Expanding mariculture farther offshore: technical, environmental, spatial and governance challenges. FAO Technical Workshop, 22-25 March 2010, Orbetello, Italy. FAO Fisheries and Aquaculture Proceedings No 24. FAO, Rome

Maes F, Röckmann C, Ulrich C, Dreyer M, Bell E, Borodzicz E, Haapasaari P, Hauge KH, Howell D, Mäntyniemi S, Miller D, Tserpes G, Pastoors M (2012) The added value of participatory modelling in fisheries management—What has been learnt? Mar Policy 36:1072-1085

MAF-Ministry of Agriculture and Fisheries (1963) Visserijwet. http://wetten.overheid.n1/BWBR0002416/ geldigheidsdatum_18-12-2015 (in Dutch)

MANFQ-Ministry of Agriculture, Nature and Food Quality (1998a) Flora- en Faunawet. http://wetten. overheid.n1/BWBR0009640/geldigheidsdatum_17-12-2015 (in Dutch)

MANFQ-Ministry of Agriculture, Nature and Food Quality (1998b) Natuurbeschermingswet. http:// wetten.overheid.n1/BWBR0009641/geldigheidsdatum_17-12-2015 (in Dutch)

MANFQ-Ministry of Agriculture, Nature and food Quality (2004) Ruimte voor een zilte oogst, Naar een omslag in de Nederlandse schelpdiercultuur. Beleidsbesluit 2005-2020. Den Haag, 1 oktober 2004 (in Dutch)

MANFQ-Ministry of Agriculture, Nature and food Quality (2008) Convenant transitie mosselsector en natuurherstel Waddenzee. (in Dutch) http://www.waddenzee.nl/fileadmin/content/Dossiers/Visserij/ pdf/21102008_convenantmossel.pdf

Mazzucato M (2013) The entrepreneurial state: Debunking public vs. private sector myths, vol 1. Anthem Press, London

McGlade JM (2002) The North Sea Large Marine Ecosystem. In: Sherman K, Skjoldal HR (eds) Large marine ecosystems of the North Atlantic. Elsevier, Amsterdam, pp 339-412

McKindsey CW, Archambault P, Callier MD, Olivier F (2011) Influence of suspended and off-bottom mussel culture on the sea bottom and benthic habitats: a review. Can J Zool 89:622-646 
MEAAI-Ministry of Economic Affairs, Agriculture and Innovation (2011) Mededeling van de Staatssecretaris van Economische Zaken, Landbouw en Innovatie van 9 December 2011, nr. 244122, betreffende het doen van een aanvraag voor een ontheffing voor het winnen van mosselzaad of het kweken van mosselen op de Noordzee. https://zoek.officielebekendmakingen.nl/stcrt-2011-22815.html (in Dutch)

MEA-Ministry of Economic Affairs (2015) Kamerbrief over SDE + Wind op Zee. https://www. rijksoverheid.nl/binaries/rijksoverheid/documenten/kamerstukken/2015/05/19/kamerbrief-oversde-wind-op-zee-2015/kamerbrief-over-sde-wind-op-zee-2015.pdf (in Dutch)

Mee L (2006) Complementary benefits of alternative energy: suitability of offshore wind farms as aquaculture sites. SEAFISH-Project Ref: 10517. http://www.seafish.org/media/Publications/10517_ Seafish_aquaculture_windfarms.pdf

Michler-Cieluch T, Krause G, Buck BH (2009) Reflections on integrating operation and maintenance activities of offshore wind farms and mariculture. Ocean Coast Manag 52(1):57-68

MIE_-Ministry of Infrastructure and Environment (2014) Verslag Noordzee 2050 Gebiedsagenda. https:// www.rijksoverheid.nl/binaries/rijksoverheid/documenten/rapporten/2014/07/28/verslag-noordzee2050-gebiedsagenda/verslag-noordzee-2050-gebiedsagenda.pdf (in Dutch)

MIE-Ministry of Infrastructure and Environment (2015) Waterberichtgeving. www.waterberichtgeving. rws.nl (in Dutch)

Mille and Blachier (2009) Mutation conchylicoles. Etat des lieux et perspectives de development des productions en eau profonde a l'automne 2008. Aglia Report febr. 2009. In: Kamermans et al. (2011)

Millennium Ecosystem Assessment (2005) Ecosystems and human well-being: synthesis. Island Press, Washington, DC

Moore SK, Mantua NJ, Salathe ET (2011) Past trends and future scenarios for environ-mental conditions favoring the accumulation of paralytic shellfish toxins in Puget Sound shellfish. Harmful Algae 10:521-529

MTW-Ministry of Transport and Water (2009) Waterwet. http://wetten.overheid.nl/BWBR0025458/ geldigheidsdatum_17-12-2015 (in Dutch)

Nam H, An S, Kim CH, Park SH, Kim YW, Lim SH (2014) Remote monitoring system based on ocean sensor networks for offshore aquaculture. In: Conference proceedings Oceans-Sept 2014 St John's

Naylor RL, Goldburg RJ, Primavera JH, Kautsky N, Beveridge MC, Clay J, Folke C, Lubchenco J, Mooney H, Troell M (2000) Effect of aquaculture on world fish supplies. Nature 405(6790):1017-1024

Oostenbrugge (2010) Verspreidingskaarten voor de Noordzeevisserij. LEI-report 2010-066. https://www. noordzeeloket.nl/images/visserijwaarde-2010-066_2887.pdf (in Dutch)

OSPAR (2009) Assessment of impacts of mariculture. OSPAR Commission, Biodiversity series. http:// qsr2010.ospar.org/media/assessments/p00442_Impacts_of_Mariculture.pdf

Philippart CJM, van Aken HM, Beukema JJ, Bos OG, Cadee GC, Dekker R (2003) Climate-related changes in recruitment of the bivalve Macoma balthica. Limnol Oceanogr 48(6):2171-2185

Philippart CJM, Anadón R, Danovaro R, Dippner JW, Drinkwater KF, Hawkins SJ, Oguz T, O’Sullivan G, Reid PC (2011) Impacts of climate change on European marine ecosystems: observations, expectations and indicators. J Exp Mar Biol Ecol 400:52-69

Poelman M, Bolman B (2010) Task 1.3 COEXIST: Inventory of possible combinations of different forms of aquaculture and/or fisheries and other activities. http://www.coexistproject.eu/images/COEXIST/ deliverables/WP1/COEXIST_245178_D1.3_FINAL.pdf

Pogoda B, Buck BH, Hagen W (2011) Growth performance and condition of oysters (Crassostrea gigas and Ostrea edulis) farmed in an offshore environment (North Sea, Germany). Aquaculture 319:484-492

Pomeroy R, Douvere F (2008) The engagement of stakeholders in the marine spatial planning process. Mar Policy 32(5):816-822

Reed MS (2008) Stakeholder participation for environmental management: a literature review. Biol Cons 141(10):2417-2431

Reijs TAM, Oorschot RWA, Poelman M, Kals J, Immink I (2008) Aquacultuur op open zee. TNO rapport 2008-D-R1048/A (in Dutch)

Reith JH, Deurwaarder EP, Hemmes K, Curvers APWM, Kamermans P, Brandenburg W, Zeeman G (2005) Bio-offshore. Grootschalige teelt van zeewieren in combinatie met offshore windparken in de Noordzee. Petten, ECN-C-05-008. https://www.ecn.nl/docs/library/report/2005/c05008.pdf (in Dutch)

Röckmann C, Stuiver M, Van Den Burg S, Zanuttigh B, Zagonari F, Airoldi L, Angelelli E, Suffredini R, Franceschi G, Bellotti G, Schouten JJ, Söderqvist T, Garção R, Guanche Garcia R, Sarmiento Martínez J, Svenstrup Petersen O, Aarup Ahrensberg N (2015) Platform Solutions; Deliverable 2.4, MERMAID project 
Rosenthal H, Costa-Pierce BA, Krause G, Buck BH (2012a) Bremerhaven declaration on the future of global open ocean aquaculture, part I: preamble and recommendations. The Bremerhaven Economic Development Company Ltd

Rosenthal H, Costa-Pierce BA, Krause G, Buck BH (2012b) Bremerhaven declaration on the future of global open ocean aquaculture-part II: recommendations on subject areas and justifications. Aquaculture Forum on open ocean aquaculture development-from visions to reality: the future of offshore farming. The Bremerhaven Economic Development Company Ltd

Rosland R, Bacher C, Strand $\varnothing$, Aure J, Strohmeier T (2011) Modelling growth variability in longline mussel farms as a function of stocking density and farm design. J Sea Res 66(4):318-330

Roycroft D, Kelly TC, Lewis LJ (2006) Behavioural interactions of seabirds with suspended mussel longlines. Aquac Int 15(1):25-36

Russi D, ten Brink P, Farmer A, Badura T, Coates D, Förster J, Kumar R, Davidson N (2013) The economics of ecosystems and biodiversity for water and Wetlands. IEEP, Ramsar Secretariat, Gland, London and Brussels

Schrum C, Alekseeva I, St John M (2006) ECOSMO, a coupled ecosystem model of the North Sea and Baltic Sea: part II. Spatial-seasonal characteristics in the North Sea as revealed by 30 EOF analysis. J Mar Syst 61:100-113

Shainee M, Ellingsen H, Leira BJ, Fredheim A (2013) Design theory in offshore fish cage designing. Aquaculture 392-395:134-141

Shumway S (ed) (2011) Shellfish aquaculture and the environment. Wiley, Oxford. ISBN: 978-0-81381413-1

Smaal AC (2002) European mussel cultivation along the Atlantic coast: production status, problems and perspectives. Hydrobiologia 484(1):89-98

Smaal AC, Schellekens T, van Stralen MR, Kromkamp JC (2013) Decrease of the carrying capacity of the Oosterschelde estuary (SW Delta, NL) for bivalve filter feeders due to overgrazing? Aquaculture 404-405:28-34

Smaal AC, Kamermans P, van der Have TM, Engelsma M, Sas HJW (2015) Feasibility of Flat Oyster (Ostrea edulis L.) restoration in the Dutch part of the North Sea. IMARES Report C028/15. http:// www.oyster-restoration.org/wp-content/uploads/2012/06/C028.15-Report-Feasibility-study-oystersA.-Smaal-jd.pdf

Steenbergen J, Verdegem MCJ, Jol JJ, Perdon J, Kamermans P, Blankendaal VG, Sneekes AC, Bakker AG, van't Groenewoud H, Hoornsman G (2005) Verkenning van mogelijkheden voor mosselteelt op open zee \& een mosselkansenkaart voor de Noordzee. RIVO-rapport nr. C088/05. http://www.we-at-sea.org/ wp-content/uploads/2013/01/RL2-2-2004-001-Mosselkansenkaart.pdf (in Dutch)

Stelzenmüller, V, Schulze T, Gimpel A, Bartelings H, Bello E, Bergh O, Bolman B, Caetano M, Davaasuren N, Fabi G, Ferreira JG, Gault J, Gramolini R, Grati F, Hamon KG, Jak RG, Kopke K, Laurans M, Mäkinen T, O’Donnell V, O’Hagan AM, O’Mahony C, Oostenbrugge H van, Ramos J, Saurel C, Sell AL, Silvo K, Sinschek K, Soma K, Stenberg C, Taylor N, Vale C, Vasquez F, Verner-Jeffreys DW (2013) Guidance on a better integration of aquaculture, fisheries, and other activities in the coastal zone: from tools to practical examples. Coexist project-Interaction in coastal waters

Stickney RR, McVey J (2002) Responsible aquaculture. CABI Press, Wallingford

Stuiver M, Gerritsen AL, Fontein RJ, Agricola HJ (2012) Multifunctionele platforms: Perspectief voor de toekomst? Aquacultuur 27(5):6-12 (in Dutch)

Suchman MC (1995) Managing legitimacy: strategic and institutional approaches. Acad Manag Rev 20:571-610

Sulaiman OO, Magee A, Bahrain Z, Othman K (2013) Mooring analysis for very large offshore aquaculture ocean plantation floating structure. Ocean Coast Manag 80:80-88

Tamis JE, de Vries P, Jongbloed RH, Lagerveld S, Jak RG, Karman CC, Van der Wal JT, Slijkerman DME, Kloky C (2016) Toward a harmonized approach for environmental assessment of human activities in the marine environment. Integr Environ Assess Manag 9999:1-11

Tidd J, Bessant J, Pavitt K (2003) Managing innovation. Wiley, Chichester

Troell M, Joyce A, Chopin T, Neori A, Buschmann AH, Fang J (2009) Ecological engineering in aquaculture-potential for integrated multi-trophic aquaculture (IMTA) in marine offshore systems. Aquaculture 297:1-9

Troost TA, de Kluijver A, Los FJ (2014) Evaluation of eutrophication variables and thresholds in the Dutch North Sea in a historical context-a model analysis. J Mar Syst 134:45-56

Utterback M (1974) Innovation and the diffusion of technology. Science 83(4125):620-626

van den Burg SWK, Stuiver M, Veenstra FA, Bikker P, Lopez Contreras AM, Palstra AP, Broeze J, Jansen HM, Jak RG, Gerritsen AL, Harmsen PFH, Kals J, Blanco Garcia A, Brandenburg WA, van Krimpen MM, van Duijn AP, Mulder WJ, van Raamsdonk LWD (2013) A Triple P review of the feasibility of 
sustainable offshore seaweed production in the North Sea. LEI report 13-077 https://www. wageningenur.nl/upload_mm/8/a/d/d69d82b9-904f-4bf1-9844-c24bd5d39346_Rapport\%2013077\%20vdBurg_DEF_WEB.pdf

van den Hoek RE, Brugnach M, Hoekstra AY (2012) Shifting to ecological engineering in flood management: Introducing new uncertainties in the development of a building with nature pilot project. Envir Sci Policy 22:85-99

Van Hoof LJW, Steenbergen J, Bolman BC, Rockmann C, Kraan ML, Piet GJ, Jak RG, van der Wal JT, Pastoors MA, Slijkerman DME, Soma K, Goldsborough DG (2014) Zee op Zicht: Inzicht; een zoektocht naar een integraal afwegingskader voor het gebruik van de zee. IMARES Report. http:// www.wageningenur.nl/nl/Publicatie-details.htm?publicationId=publication-way-343835313839 (in Dutch)

Van Nieuwenhove K (2008) Studie naar de commercialisering van de Belgische off-shore hangmosselcultuur. WP3. Uitbreiding van schelpdierproductiegebieden. ILVO-rapport Mei 2008 (in Dutch)

Van Slobbe E (2010) Ecodynamic Design as a boundary object. A case study in Fryslan. ERSCP-EMSU conference, Delft, The Netherlands, 25-29 October 2010

van Slobbe E, Lulofs K (2011) Implementing "Building with Nature" in complex governance situations. In: Terra et Aqua No. 124 (2011). https://www.iadc-dredging.com/ul/cms/terraetaqua/document/2/9/8/ 298/298/1/article-implementing-building-with-nature-in-complex-governance-situations-terra-et-aqua124-2.pdf

Van Stralen MR (2013) Invang van mosselzaad in MZI's, resultaten 2012. Marinx-rapport 2013.126. Scharendijke (in Dutch)

VPS (2008) Aquaculture growth key success factors for aquaculture development. Venture Positioning Services

Walter U, Liebezeit G (2003) Efficiency of blue mussel (Mytilus edulis) spat collectors in highly dynamic tidal environments of the Lower Saxonian coast (southern North Sea). Biomol Eng 20(4-6):407-411

Wesselink A, Paavola J, Fritsch O, Renn O (2011) Rationales for public participation in environmental policy and governance: practitioners' perspectives. Environ Plan 43(11):2688-2704

White C, Halpern BS, Kappel VC (2012) Ecosystem service tradeoff analysis reveals the value of marine spatial planning for multiple ocean uses. Proc. Natl. Acad. Sci. U. S. A. 109:4696-4701 